\title{
WIND ENERGY USE AND WIND ENERGY POTENTIAL OF THE REPUBLIC OF SRPSKA
}

\author{
D. Lj. Mirjanić, ${ }^{1, *}$ M. Zlatanovic ${ }^{2}$ \\ ${ }^{1}$ Academy of Sciences and Arts of the Republic of Srpska, Republic of Srpska \\ ${ }^{2}$ Belgrade University, Faculty of Electrical Engineering, Serbia
}

\begin{abstract}
In the energy sector important increase in the use of renewable energy sources has been caused by climate changes, which are, in turn, a result of greenhouse gas emissions and the pollution of the environment. The energy of the wind is the most important environmentally- friendly renewable energy source, and is, by many economic parameters, a successful competitor to classical energy sources. The countries of the European Union, as well as America, China, India, Australia and many other countries have introduced substantial government measures to support the development of the wind power energy.

By using the satellite data, Company ANEMOS developed the RS Wind Atlas in 5 $\mathrm{km} \times 5 \mathrm{~km}$ resolution. The data from land meteorological stations in the territory of RS may be used only to a limited extent due to the spatial distribution of measurement places and large influence that the configuration and roughness of the surrounding area have on the interpretation of measurement results. A number of specialized measurement stations for wind in the territory of the Romanija and around Trebinje have been installed in order to determine the local energy potential of the wind. This paper outlines the first results of determining global distribution of speed of wind in the RS territory according to the European Atlas methodology, by using the satellite measurements with $25 \mathrm{~km}$ x $25 \mathrm{~km}$ resolution. It has been shown that the wind speed in the territory of RS rises in the direction North-West - South-East, which is corresponding to the available results of other studies. The wind maps that were produced may be used to determine the locations that are appropriate for setting the specialized measurement stations for wind.
\end{abstract}

At the end of the paper we analyze economic aspects of using the wind energy.

Keywords: wind energy, wind generators, the Republic of Srpska Wind Atlas.

\section{INTRODUCTION}

It was a long, long time ago that a man noticed that the energy of the wind that exists in abundance in nature can be used. As long as 3000 years B.C. the old Egyptians would sail the Niles upstream, using favorable winds. Throughout history new roads and even new continents were discovered by using the wind energy; the ships driven by the wind were abandoned only after the discovery of faster and more efficient drives.

The first written records on application of the energy of the wind for generation of mechanical operation also date back to the ancient time, more precisely, to 2000 years B.C. This was a simple windmill with a vertical shaft, i.e., with horizontal blades to which the sails were attached 'capturing' the wind and which served to drive the mill for grinding grain. The written records about the windmills in the territory of Egypt, Mesopotamia and China date back to that time. Apart from driving the mills, windmills were used in those old times to drive the pumps for drinking water and/or for irrigation.

In the European countries, the first applications of the Wind energy were recorded only in the early Middle Ages, more precisely, in 7th century. But it was also in Europe that an important innovation - windmills with horizontal axis of the shaft were invented. Parallel to the development of the technology for conversion of the kinetic energy of the wind into mechanical operation the application of the wind energy for use in transport was developed, so that new designs of ship sails were discovered which made transport faster and faster and physical distances smaller concerning the required traveling time.

Although they can be found anywhere in the world, it is somehow common to associate the windmills with the Netherlands. In a country whose two thirds of the area is even nowadays below the 
sea level, the windmills for driving the pumps for water for drying the soil were used as early as in the year 1000 . At the beginning of 17 th century the Dutch used 26 windmills to dry up the entire Beerster lake, $3 \mathrm{~m}$ deep.

Middle Ages are certainly considered as ,the golden era" for windmills. New improvements were constantly found (e.g. twisting the blades in order to make the best use of the wind, and even Leonardo da Vinci was preoccupied with their development). In the late Middle Ages they started to be applied for other purposes, for instance for driving the machines (hammers, saws, etc.) in different plants for manufacture, while the first hybrid plants were recorded that simultaneously used the energy of water and the wind.

In mid-19th century, approximately at the time of the expansion of use of steam machines, about 50.000 windmills operated in Europe; that number, however, as of the beginning of 20th century, has fallen to only 10.000 windmills. At the beginning of 20th century a more significant was of electrical energy; this resulted in a certain renaissance of windmills in the second half of the century as the windmills were transformed into the noted plants for electricity production - i.e. wind power plants.

In modern days, the global development implies taking care of the environment; in that context, a term often used is sustainable development. An uncontrolled development, focused only on the concrete goal of certain human activity to be as efficient as possible, could lead to such disturbances in the environment that could destroy the entire civilization. The essence of sustainable development implies continuous monitoring of changes in the environment technological progress and all other human activities in order to be controlled.

The atmosphere of the planet Earth, with its climate that is one of the kinds in the part of the cosmos accessible to our sight, enabled the development of life on Earth. The development of civilization relies on the conversion of the energy into the forms that we can both use and control at the current level of technological development. There are two main shortcomings with regards to the most important sources of energy and the way we use it, from the point of view of sustainable development - the reserves of conventional energy sources are limited, and the way in which we use them is greatly detrimental to the environment, with a possibility of leading to negative climate changes.

At this level of the development, the solution is seen in the use of renewable energy sources that are environmentally-friendly. The action that was run at the global level resulted in the adoption of the documents the purpose of which was to ensure that by the year $202020 \%$ of necessary energy in the European Union and the USA is produced from renewable sources. [2,3]. The energy of the sun is a dominant renewable energy source; appears on the Earth also in the form of wind. The wind is the most significant renewable energy in modern electricity production, because the cost of its conversion into electrical energy is competitive with the cost of classical energy sources.

As is the case with the other energy sources, the energy of the wind is not evenly distributed in atmospheric boundary layer above the surface of the Earth. The energy of the Sun that reaches us through the electromagnetic waves causes uneven heating of the surface of the Earth and the air above, leading to the difference of temperature and pressure in certain areas and in the movement of the air masses, that is to say, to the conversion of the radiation energy into mechanical energy of the wind. Global winds are a consequence of both uneven heating of the surface of the Earth and its rotation, proportion of the surface and distribution of land and water masses as well as the land configuration.

The Balkan peninsula is located in the area of western global winds, however, we know from the experience that the global picture of winds largely departs from the characteristics of local winds, the energy potential of which is the only relevant when it comes to using the wind as a renewable energy source.

The distribution of the energy potential of wind in atmospheric boundary layer is presented as a function of height above the area determined by the geographic position, i.e. geographic coordinates. The graphical layout consists of geographic maps with drawn speed (and the direction), i.e. density of power of the wind at a certain height. The set of such maps constitutes the wind atlas. With an exception of meteorological maps, the first systematic development of wind atlases, designed for the use of the wind energy, was a result of a European project and is entitled the European Wind Atlas [4]. The methodology that was designed for the purposes of this Atlas by the Danish Institute RISO is still used nowadays.

A more significant application of the energy of the wind for electricity generation started in the years after the so-called first energy crisis, in the 70s of the last century in Denmark and USA (California). In the next few years, in these two countries, as well as in a few more West-European countries (Great Britain, the Netherlands, Sweden and Germany), an extensive programs of construction of wind power plants (wind farms) was initiated and necessary equipment started to be produced. These countries have been lately followed by some Medi- 
terranean and Asian countries. In the world today, there are many manufacturers of the equipment for wind energy use, and at least one wind power plant (commercial or test) can be found in every country of the world having potentially good wind.

The competitiveness of wind turbines in an increasingly liberalized electricity market has been lately affected by different state subsidy programs, mostly in the form of tariff incentives (per produced $\mathrm{kWh}$,), investment incentives and tax or fiscal measures.

No commercial wind power plant has been built in the Republic of Srpska so far.

This paper presents the Republic of Srpska Wind Atlas produced according to the data from satellite observations and designed in overall resolution $25 \mathrm{~km} \times 25 \mathrm{~km}$ [5].

\section{BASIC CHARACTERISTICS OF THE WIND AND CONVERSION OF THE ENERGY IN A WIND TURBINE}

The flow of the air masses at the local level is influenced by the local characteristics of the surface of soil, because, during the flow of air, as of any other fluid, friction occurs, i.e., losses of kinetic energy in contact with hard surface resulting in the differences of the speed of flow in space and time [1].

The present speed of the wind may be presented as a sum of mean wind speed and the fluctuating component of wind speed $\left(v=v_{s r}+v_{f}\right)$.

Longitudinal intensity of turbulence is determined by the fluctuating component of wind speed; this turbulence is at the following level:

$$
T u=\frac{\sigma_{u}}{v_{s r}}=\frac{1}{v_{s r}}\left(\sqrt{\frac{1}{T} \int_{O}^{T} v d t-v_{s r}^{2}}\right)^{1 / 2},
$$

where

$T u$ - is the intensity of turbulence in longitudinal direction $(0,15-0,2$ for areas under trees and buildings, $\neq 0,1$ for flat surface),

$\sigma_{u}-$ standard deviation and

$T$ - averaging period.

The speed of air i.e. wind flow along the very surface of the soil is equal to zero and it speedily grows with the height, while at the upper limit of atmospheric boundary layer (about $2 \mathrm{~km}$ above the ground on a summer day) the change of the speed with the height equals to zero. The change of profile of air flow speed by the height, i.e. the vertical wind speed gradient may be presented by different simplified and approximate functions, whereby the formu- la below is most frequently used for the heights up to a few dozens of meters above the ground, while neglecting the thermal structure of atmosphere, namely:

$v(z)=v_{r e f}\left(\frac{z}{z_{r e f}}\right)^{\alpha}$,

where

$v-$ is the speed of wind (as a function of height),

$v_{r e f}-$ is the speed of wind at the reference height,

$\mathrm{z}$ - is the height,

$Z_{\text {ref }}$ - is reference height, and

$\alpha$ - exponent that depends on the appearance of ground surface.

In logarithm form, it is most frequently presented in the following way:

$\frac{v(z)}{v_{10}}=\frac{\ln \left(\frac{z}{z_{o}}\right)}{\ln \left(\frac{10}{z_{o}}\right)}$,

where

$v_{10}$ - is the speed of the wind at $10 \mathrm{~m}$ above the surface of the ground and

$\mathrm{z}_{o}-$ is the roughness length.

The expected values, i.e. probabilities of occurrence of some wind speed over a time period may be presented by a histogram made on the basis of data on the winds in an area, collected over a longer time period, e.g. a number of years. By connecting the highest probability values for each value of wind speed, a curve, i.e. a function of probability density is obtained, that can be presented by Weibull function:

$p(v)=\frac{k}{C}\left(\frac{v}{C}\right)^{k-1} e^{-\left(\frac{v}{C}\right)^{k}}$,

where

$p(v)$ - is the frequency of the event of a specific wind speed $v$,

$k$ - is the shape parameter (for Rayleigh distribution it amounts to 2) and

$C-$ is the scale parameter.

Data on wind directions and speed are obtained on the basis of meteorological observations and measurements carried out at meteorological stations according to the unique rules laid down by the World Meteorological Organization (WMO).

Conversion of the kinetic energy of the wind into the kinetic energy of shaft rotation is carried out by way of wind turbine rotor blades. The wind turbine rotor and electrical generator are located on the same shaft or on two shafts coupled by a gear box. The conversion of the kinetic energy of wind turbine 
shaft rotation into the electrical energy output takes place in the generator, so that the whole plant is sometimes referred to as the wind generator instead of wind turbine generator (WTG), but actually we are speaking of a single wind power electricity plant.

One or more wind turbines with related equipment make a wind power plant (wind farm). A wind farm or a wind park is the system consisting of several interconnected wind power plants a wind farm or a wind park.

Having said that, The term wind power plant implies the plants for production of electrical power, while the term windmill implies the plants for producing mechanical energy to powermechanical equipments such as the mills, water pumps or similar.

Power density or specific power of the wind is proportional to the third degree of its speed, and, for the constant wind speed and the surface perpendicular to the flow direction, it amounts to [1]:

$P=\frac{\rho v^{3}}{2}$,

where

$P-$ is the overall specific power of the wind $\left(\mathrm{W} / \mathrm{m}^{2}\right)$, $\rho=\rho_{0} \frac{288 \rho_{B}}{760 T}-$ is the air density $\left(\mathrm{kg} / \mathrm{m}^{3}\right)$,

$\rho_{0}-$ is the density of the air at standard conditions,

$\rho_{B}-$ barometric (atmospheric) pressure,

$T-$ is temperature of the air, and

$v-$ is the wind speed.

In general case, the speed of the wind is not constant, therefore, the specific power equals to:

$P=\frac{1}{2 T} \int_{0}^{T} \rho v^{3}(t) d t$.

The hill tops, the regions exposed to the sea coasts and the open sea are the most windy areas. Besides the average value of wind speed, there are numerous other factors that are important for designing a wind power plant. Wind statistics based on Weibull distribution of frequency of wind speed occurrence together with the surface roughness, orography, wind speed vertical gradient and some other meteorological data were used for the assessment of wind energy potential at selected location.

The kinetic energy of the wind in the air flow for the time interval $T$ in which the wind speed is considered as constant, has the following form

$E=\frac{1}{2} \rho v^{3} T$,

where

$E$ - is the kinetic energy of the wind.

According to thermodynamic low there exist the maximum part of the total kinetic energy of the wind that can beconverted into the kinetic energy of the rotor blades or into any other kind of wind energy converter, in order to enable the flow of the air downwind the converter. This fact is referred to as the Betz's law, and can be expressed mathematically as the ratio of the available power at the wind turbine shaft and the power contained in non perturbated wind flow upwind the converter

$c_{p}=\frac{P_{t}}{P}=P_{t} / \frac{1}{2} \rho v^{3}$,

where

$c_{p}$ - is the degree of aerodynamical conversion $(0,45$ for modern wind turbines), $P_{t}-$ is the transformed power $\left(\mathrm{W} / \mathrm{m}^{2}\right)$.

The highest possible value of the degree of aerodynamical conversion is is $c_{\mathrm{p}, \max }=0,593$ and is referred to as Betz limit Hence, above this value the efficiency of any plant for using the wind energy cannot be improved, no matter what improvement methods are used, that is to say:

$P_{t, \max }=0,593 \frac{\rho v^{3}}{2}$.

Taking into account the other losses that occur during the processes of energy conversion in a wind power plant, it turns out that only a little below $1 / 2$ of the initial (total) kinetic energy of the wind can be converted into useful energy, i.e. electric energy.

\section{WIND GENERATORS AND WIND POWER PLANTS}

Wind turbines are the main devices for conversion of the energy of the wind. There are two principal types ofwind turbines:

- wind turbines with vertical axis where the axis of the rotation is vertical relative to the horizontal ground (and approximately perpendicular to the direction of the wind) and

- wind turbines with horizontal axis (in the form of propellers) where the rotational axis is horizontal to the ground (and approximately parallel to the direction of the wind).

Horizontal turbines are more frequently used (95\%) due to their simpler construction and the possibility to operate at higher wind speeds. following:

Horizontal turbine components are the

- rotor with blades that turns the energy of the wind into the energy of blades rotation,

- a nacelle that contains drive train with the low and high speed transmission shafts, the gearbox and the generator,

- tower, that carries the rotor and the nacelle, 
- electrical equipment, such as controllers, electrical cables, land support equipment and connecting equipment.

Towers are mainly made of steel, while the wings are from reinforced fiberglass or epoxated wood.

Wind turbine generators (WTG) are commonly grouped into a large wind power plants (660 kW and more) which are also known as WTG farms. Electrical power produced in these farms are transported to the grid from where it is distributed to consumers [10].

Wind turbine generator farms may be of different power, starting with a few MW to several hundreds MW. Wind power plants are „modular“, which means that they consist of small individual modules (turbines) which can be easily upgraded to the farm system, thus producing the systems that can be bigger or smaller, as necessary. Turbines may be upgraded as the need for electricity rises. Presently, $50 \mathrm{MW}$ farms of WTG can be fully constructed in 18 months to two years. Most time is needed for evaluation of the resources and procurement of appropriate licenses, while the construction of the farm itself takes six months.

Turbines may be of different sizes. The biggest plants have a range of blades that is bigger than the length of a football stadium, almost as high as 20-storey buildings; they produce enough electricity to supply 1400 households. The big WTG plants that are used onshore WTG farms, have a rotor diameter significantely exceeding $100 \mathrm{~m}$ of with the towers arounf $200 \mathrm{~m}$. of approximately the same dimensions. A plant that is $90 \mathrm{~m}$ big at $90 \mathrm{~m}$ high tower has the total height, from the base to the end of the rotor, of about $135 \mathrm{~m}$.

Turbines placed in coastal areas have large rotors, and currently the biggest turbine at the open sea has a rotor with $150 \mathrm{~m}$ in diameter. PRotor blades are much more easily transported by ship than by land.Electrical energy produced in such big plants, along with the electricity produced in other types of power plants, is transported via transmission lines and distributed to the consumers. $6 \mathrm{MW}-$ power turbines are presently being tested.

Ranges of power produced by medium-size wind generators from a few hundreds of volts up to $50 / 60 \mathrm{~Hz}$ frequencies. By using the transformers, voltage is increased to $10-30 \mathrm{kV}$, from which corresponds to medium-voltage grid.. Wind generators of medium power of up to a few dozens of kilowatts produce three-phase current and are usually connected to the low-voltage distribution grid.

Small turbines that are used to supply housing and business units have a rotor diameter of about 8 $\mathrm{m}$ or smaller and are mounted on up to $40 \mathrm{~m}$ high towers. Small and very small wind generators up to $3 \mathrm{k} \mathrm{W}$ of power are made by direct connecting of the propeller and power generator without the transmission mechanism (gearbox), by which their cost is reduced. Small wind generators are intended for individual use and are most frequently used for charging the batteries in the areas without the electricity grid, while the energy is usually used for lighting and TV sets.

Modern wind generators start producing the electricity at as low speed of wind as $2.5 \mathrm{~m} / \mathrm{s}$, and are stopped for safety reasons at the speed of $25 \mathrm{~m} / \mathrm{s}$. The wind generator is capable of ensuring the economical power production if the average annual wind speed is higher than $6 \mathrm{~m} / \mathrm{s}$.

Wind generator productivity depends on the size of the turbine and the speed of the wind turning the rotor. Turbines that are produced nowadays have the power of $250 \mathrm{~W}$ to $7 \mathrm{MW}$. For example, a turbine of $10 \mathrm{~kW}$ power can produce $10.000 \mathrm{kWh}$ of electrical energy per year, with the average speed of wind of $19 \mathrm{~km} / \mathrm{h}$, which covers the needs of an average household. A turbine with $5 \mathrm{MW}$ of power can produce a little more than 15 million $\mathrm{kWh}$ on the annual basis, which is sufficient for supplying 1.400 households. Many manufacturers offer the turbines within the range of $700 \mathrm{~kW}$ to $2.5 \mathrm{MW}$.

Wind speed is the most important element affecting the turbine performances. Wind speed is measured at the location before installing the system, when evaluating the wind energy resource. Essentially, it takes the average annual speed higher than $4 \mathrm{~m} / \mathrm{s}$ to operate the small turbines (less wind is necessary for pumping water), while for the operation of the wind power plant the least average speed of wind of $6 \mathrm{~m} / \mathrm{s}$ is necessary.

Capacity factor is one of the elements in evaluation of the productivity of the wind turbine or some other plant. It shows a ratio between the power generated during a certain period and the power that would have been obtained had the turbine been operated at the maximum output power $100 \%$ of time [11]:

$F_{c}=\frac{P_{t}}{P_{u}}$,

where

$F_{c}$ - is a capacity factor,

$P_{t}$ - is the real amount of power obtained during a certain period and

$P_{u}$ - is the power that would have been obtained had the turbine been operated at the maximum output power $100 \%$ of time.

Conventional fuel powered plants are operated normally - without an interruption - unless there 
is some sort of breakdown. Their capacity factor is usually from $40 \%$ to $80 \%$.

Although the modern turbines run $65 \%$ to $90 \%$ of time, they usually do not work at full capacity, so that the capacity factor from $25 \%$ to $40 \%$ is usual, although higher capacities are achieved during the windy weeks and months. With a very big rotor and a small generator, a turbine would operate at full capacity each time the wind blows and would have a $60-80 \%$ capacity factor, however it would produce very little power. The highest power per money invested is achieved by using big generators and by accepting the fact that this will result in a lower capacity factor. This is what makes the wind power plants different from the fuel-run power plants.

Due to the friction between the air and the ground, as well as due to internal viscous friction, the speed of the wind increases with an increase of the height above the ground. The wind speed profile is influenced by unevenness on the ground, the presence of natural and artificial obstacles, as well as other topographical elements. When choosing a location, one should take into account that the best possible annual speed of the wind is reached. This has a direct impact on the quantity of produced electrical energy. Even the small mistakes in the selection of the best possible location over a long-term balance of the production result in significant decreases in return on investment.

\section{METHODOLOGY OF ATLAS DESIGN}

The atmospheric boundary layer is a part of atmosphere that lies directly above the surface of the ground. The thickness of such a layer (height above the ground) changes depending on the time of the day as well as on many other factors. Movement of air masses through this layer depends on the form of the surface at the level of the dimensions characterizing the terrain configuration - relief, i.e. orography, at the level of finer details of surface geometry such as a water surface, pastures crops, forests, inhabited areas, and the like - the so-called roughness of the terrain. Certain obstacles, i.e. individual objects in the direct vicinity, such as built structures, poles, individual trees etc. have an influence on the characteristics of the local wind too. The influence of orography, roughness and obstacles on the characteristics of the movement of air masses on the observed location is determined on the basis of physical models. These models include the laws of preserving the mass, momentum andenergy, as well as the conditions at the air-ground surface interface. Models successfully simulate the movement of air masses above the relatively flat surface of homogenous roughness without major concentration of obstacles. By taking into account certain details, it is possible to successfully simulate wind characteristics in mountainous areas too. Determining the turbulence caused by windmills, may serve as an illustration of the need to improve the model. Presently it is not possible to determine, with great precision, air turbulences within a group of wind mills, the so-called windturbine farms or windpark. This is important in order to determine the decrease of energy potential of the wind at the place of selected wind turbine due to the influence of other windturbines; it is also important for determination of mechanical strain sustained by the turbine blades the diameter of which, with higher power modern turbine, exceeds $100 \mathrm{~m}$.

The following methodology was used during the designing of the European Wind Atlas: longterm data of measurement were collected from a largenumber of meteorological stations in the territory of the European Union member states. Speed and direction of the wind, pressure and temperature are especially relevant. Sensors that are used for measuring give local values at meter location. Height above the ground on which the measurement is done, as well as orography and roughness of the surrounding terrain and distribution of obstacles in the vicinity of the measurement station have an impact on measured values. After verification of data on the basis of the set criteria, modeling of the measuring station was performed. This implies determining the impacts of orography, roughness and obstacles on local characteristics of the wind. The height profile of the speed and of the direction of the local wind depends on these characteristics. Based on the model, it is possible to determine the expected wind characteristics in the area surrounding the measuring station above the ground of given typical roughness as well as at characteristic heights above the surface. This data characterizes the local wind climate. It is possible to determine the wind characteristics in the broader area between remote meteorological stations by using linear extrapolation or another more precise method. The data obtained for certain geographical areas make up a wind atlas that can be presented graphically or in the form of a table with the data on the average speed of the wind and the density of the power for a number of characteristic terrain roughness and for a number of characteristic heights above the ground. This data, in the resolution of a number of dozens of kilometers, may serve to determine a broader area within which it is possible to install specialized measuring stations for determining the wind characteristics. 
The described methodology was used in the programme package WAsP (Wind Atlas Analysis and Application Program www.wasp.dk). In terms of the positions in the nodes of selected homogenous network on the surface, the program provides data on the speed and the density of the wind power, altitude of the ground, as well as the other data for the given height above the ground in the surroundings of the measuring station. The resolution of the wind map is determined by the density of nodes in the network. Instead of the measured database, the program uses statistical analysis that represents the wind characteristics by two-parameter Weibull distribution. In addition to the average speed and the density of the wind power, Wind Atlas contains the values of distribution parameters. One of the European Wind Atlas's maps is shown in Figure 1 [4].

WAsP uses the linear model. There are also other models, such as a model of the most probable condition of atmosphere, mezzo model, etc. The essence of usability of wind atlas in terms of using the energy of the wind is determined by the quality of measuring data. If there is measuring data at the location of the wind mill at the height of turbine axis, over a sufficiently long period of time, no models will be necessary in order to determine, for example, the average annual production of electrical energy during the exploitation age of the selected wind turbine.

In addition to the international exchange from land meteorological stations, meteorological data is constantly collected by way of remote observation from the satellites. The data on the direction and the speed of the wind in atmospheric boundary area at a certain height above the ground are collected by satellites from all over the planet. It was shown that at the present degree of the measurement technique, the data obtained by remote observation above the ocean and big water surfaces was very reliable and that it can be used to design wind power plants in shallow waters of the oceans and the seas. However, for the needs of determining the locations of wind power plants inland, the precision of satellite measurements of the wind is still insufficient.
Due to the lack of digital data on the wind from meteorological stations in the territory of the Republic of Srpska, in this paper we used the satellite data for determining the Wind Atlas in $25 \mathrm{~km} \times 25$ $\mathrm{km}$ resolution.

\section{DATA USED TO MAKE THE REPUBLIC OF SRPSKA WIND ATLAS}

The system of meteorological stations in the Republic of Srpska is presented in Figure 2. These stations are included in the network of the Republic Hydrometeorological Institute in Banja Luka.

Looking at the borders of the Republic of Srpska, the number and the distribution of the stations are satisfactory. However, in terms of the needs to develop a wind atlas, it would be more suitable to include the data from the stations that are distributed closer to the square coordinate grid. Lack of the data on the wind in the digital form, over a longer time period is the main reason for the decision not to use the data of the said stations for designing the wind atlas. Besides, modeling the stations for the sake of including the impacts of orography, roughness and obstacles is very complicated. For example, during the designing of the European Wind Atlas, the data from the airports were used to a great extent, which makes determination of roughness of the terrain and the impact of the local orography easier.

In order to determine the energy potential of the wind inland, the most reliable are the measurings of the wind from the specialized wind measurement stations located near the location where the construction of wind park is planned. In the Republic of Srpska such measurings take place in a number of locations, which is not sufficient for forming the wind atlas, but can be used for the verification of atlases produced in some other ways.

In 2001, the HZ HB Electric Power Utility in Mostar (EP HZHB) started a research and the development of the project of the use of wind, aided with the funds from the Government of Spain. 


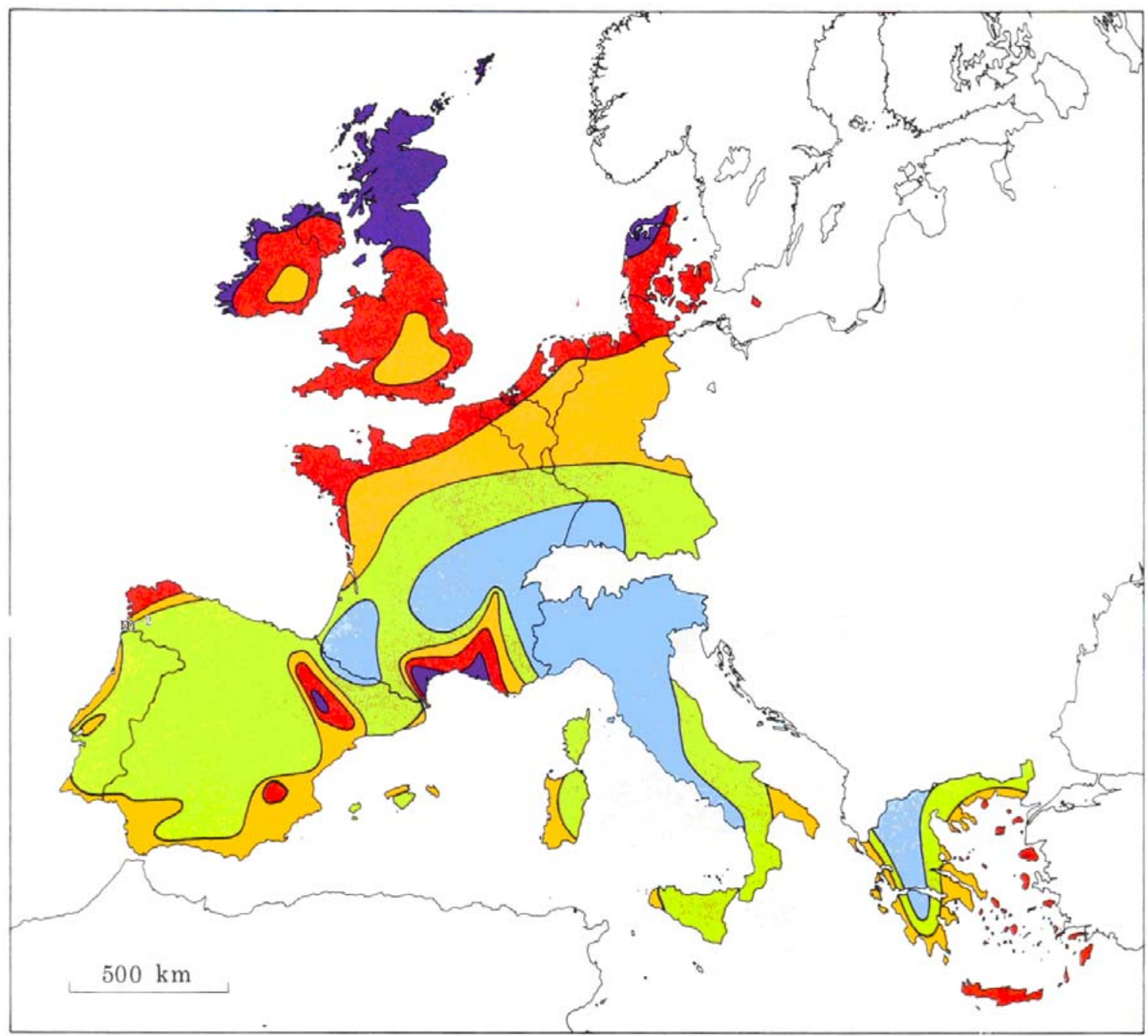

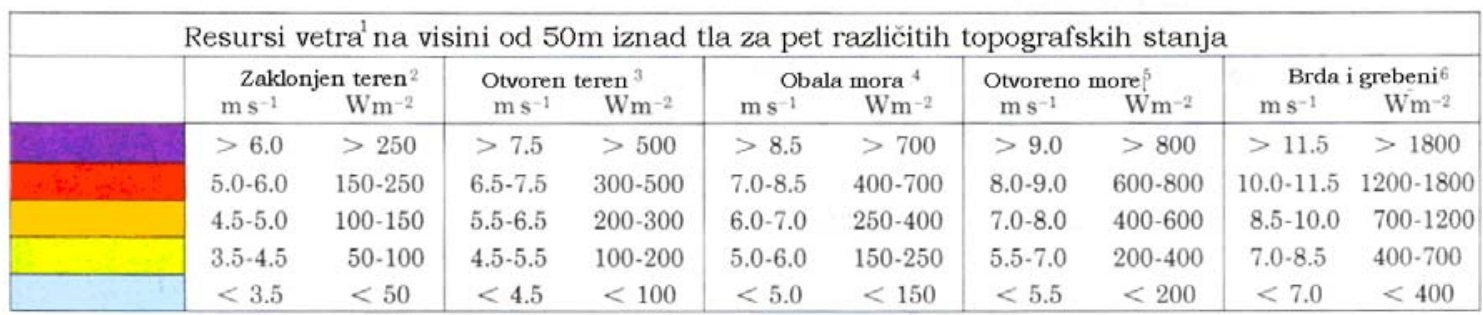

Figure 1. European Wind Atlas

Table 1. Designations of meteorological stations in the RS

\begin{tabular}{|c|c|c|c|c|c|c|c|}
\hline 14530 & Drinić & 14538 & Srbac & 14547 & Šipovo & 14562 & Bijeljina \\
\hline 14531 & Ribnik & 14539 & Gradiška & 14550 & Derventa & 14563 & Zvornik \\
\hline 14534 & Mrakovica & 14542 & Banja Luka & 14551 & Doboj & 14564 & Srebrenica \\
\hline 14535 & Novi Grad & 14545 & Mrkonjić Grad & 14555 & Petrovo & 14565 & Han Pijesak \\
\hline 14536 & Prijedor & 14546 & Kneževo & 14649 & Nevesinje & 14655 & Gacko \\
\hline 14656 & Čemerno & 14658 & Sokolac & 14662 & Višegrad & 14663 & Rudo \\
\hline 14664 & Čajniče & 14665 & Foča & 14667 & Bileća & 14668 & Trebinje \\
\hline
\end{tabular}




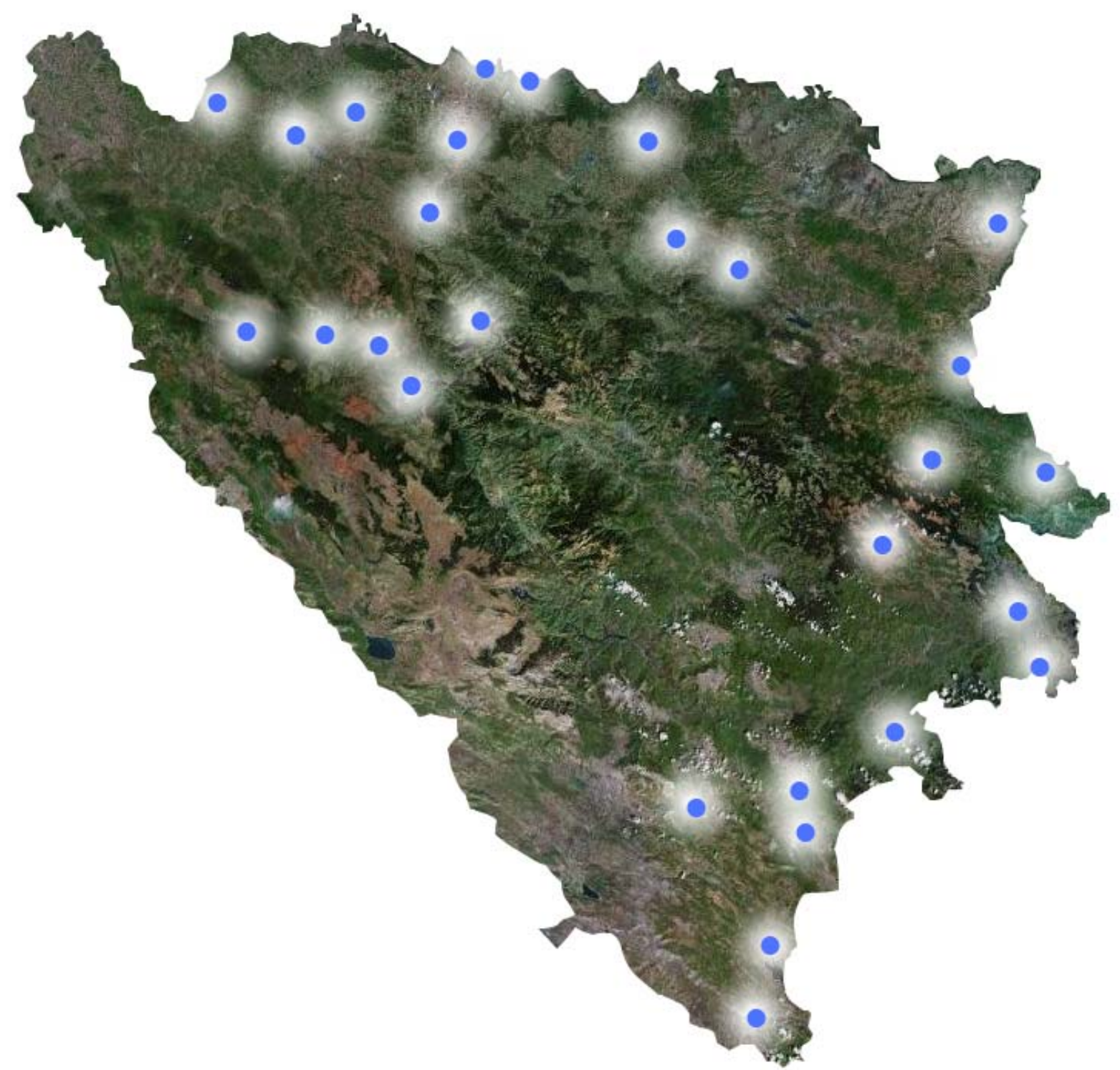

Figure 2. System of meteorological stations of the Republic of Srpska

Based on the project of a foreign consultant company, 10 measuring poles, $10 \mathrm{~m}$ high and 3 poles $50 \mathrm{~m}$ high have been installed.

Based on the measuring results, during the campaign that lasted for longer than a year, a map was formed with an indicated technically useable wind potential, presented in Figure 3. The feasibility study demonstrated that even three wind parks were possible to be built in the designated area. The feasibility project was developed for the area with the highest determined energy potential, based on measurements.

The data on the wind from the satellites can be used for making the wind atlas in a wider area. Stationary satellites in polar orbit furnished with
Doppler LIDAR for measuring the speed of wind can be used in principle for forming the database above the surface of the Earth. This method of measuring produces far more accurate data for determining the energy potential of the wind in coastal areas; on the other hand, the technique of satellite measurements inland is also increasingly improved. The quality of data reaches the quality of radio-probe measurement with meteorological balloons. However, the most precisely obtained ten-minute results of satellites measurements of wind characteristics are not publicly available; the data is available only in rough space and time resolution. The appearance of a satellite equipped with Doppler LIDAR is presented in Figure 4. 


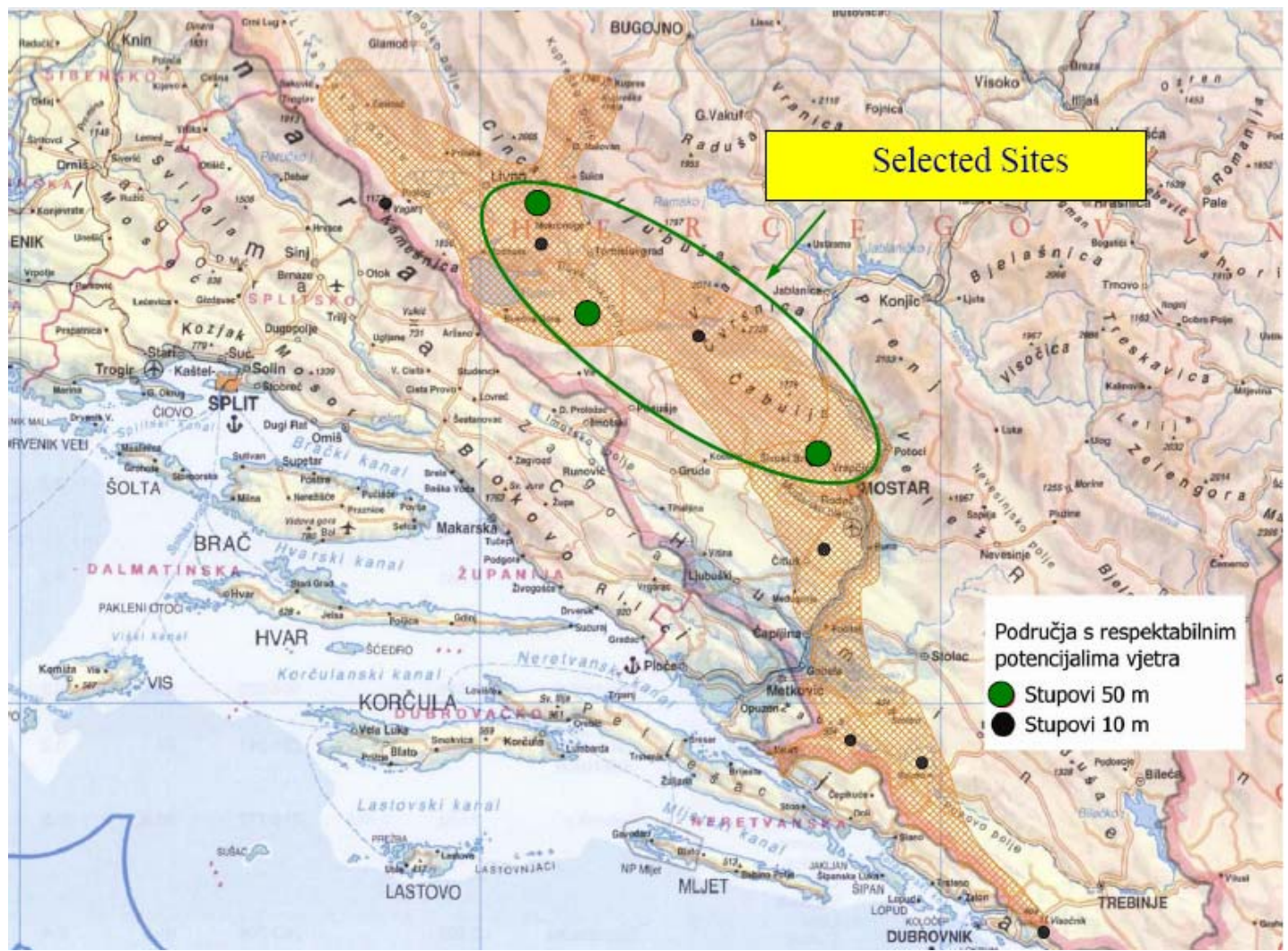

Figure 3. The area with technically high-useable potentials of the wind in the area of HZBH in BiH

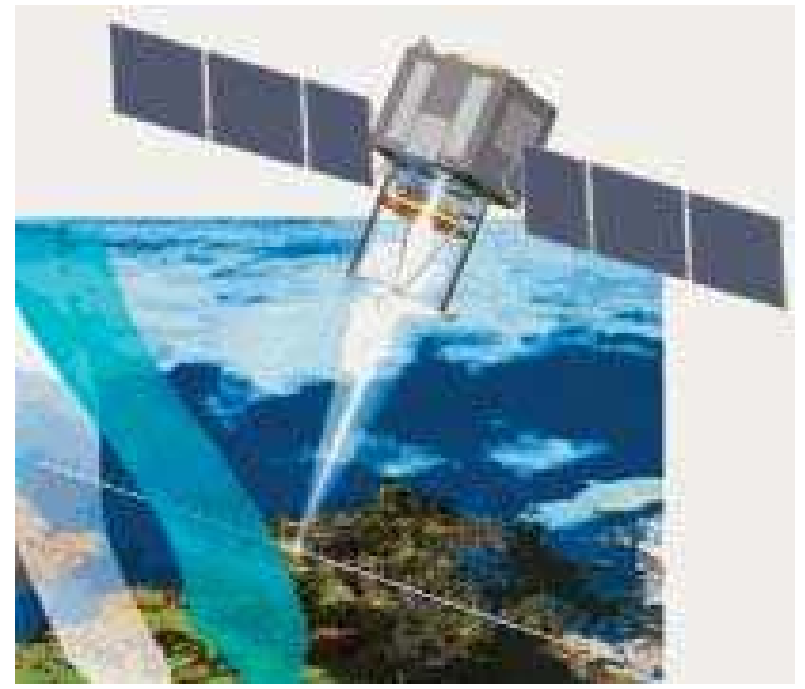

Figure 4. Presentation of measuring the wind speed by way of Doppler LIDAR

NASA, through its program Earth science research, provides the data of relevance for the studies of climate and climate changes. Databases include long-term data of estimated meteorological parameters and the data on solar energy flux on the surface of Earth. The following is relevant for determining technically usable energy potential of the wind:
- Studies of evaluation of the energy potential of the wind over a longer time period require homogenous databases in terms of space and time, of high resolution, as well as the data on terrain orography.

- Data from the satellite measurements over a longer period of time can be used to develop a wind atlas, as well as the satellite data on terrain orography.

\section{METHODOLOGY OF MAKING WIND ATLAS BASED ON SATELLITE DATA}

Graphic presentation of data on the wind within the program NASA GMAO GEOS-1 is shown in Figure 5.

The intensity and the direction of the wind speed are given up to the height of $4000 \mathrm{~m}$, depending on the measuring mode, and then data was extrapolated at the level of the surface of the ground. The direction of the banner represents the direction of the wind, while the color of the banners corresponds to the speed intensity.

The Table 2. containing the results of measuring of wind speed for each month at the height of $50 \mathrm{~m}$ above ground. Averaging was done for a 10 - 
year period (the example was given for the period July 1983 - June 1993). The data were collected every three hours.

The database contains a range of meteorological parameters homogenously distributed in space and time. When using the database, first an appropriate area is selected at the surface of the land by selection of geographic coordinates or directly, by clicking on a certain segment in graphical presentation of the ground. Spatial resolution of the base is defined by the grid coordinate, therefore a certain segment of grid is being actually selected. The table containing the satellite data on the wind for the selected segment in parallelogram defined by geographic coordinates of the cross-section of its diagonals is presented in Figure 6. The table contains the average monthly values of speed intensity at the height of $50 \mathrm{~m}$ above the ground averaged for the whole segment and for the averaged altitude of segment surface. Long-term data imply averaging by time and for a 40 -year period.
Graphic presentation of the grid segment for which wind data was averaged is shown in Figure 6. It is also possible to take over average monthly values of speed for certain hours during the day when the measuring was done (Table 2), while the data on the direction of the wind is shown in Table 3.

Besides the presented types of databases, the following databases exist too:

- Difference between maximum and minimum average monthly speed at the height of $50 \mathrm{~m}$ in $\%$,

- Modeled mean speed and direction of the wind at the height of $10 \mathrm{~m}$ above the ground, the roughness of which corresponds to the ground which, by surface characteristics (roughness) is similar to an airport, and

- Average modeled wind speed at various heights depending on the presumed ground roughness.

\section{Data Collection-Data Merging (2 of 3)}

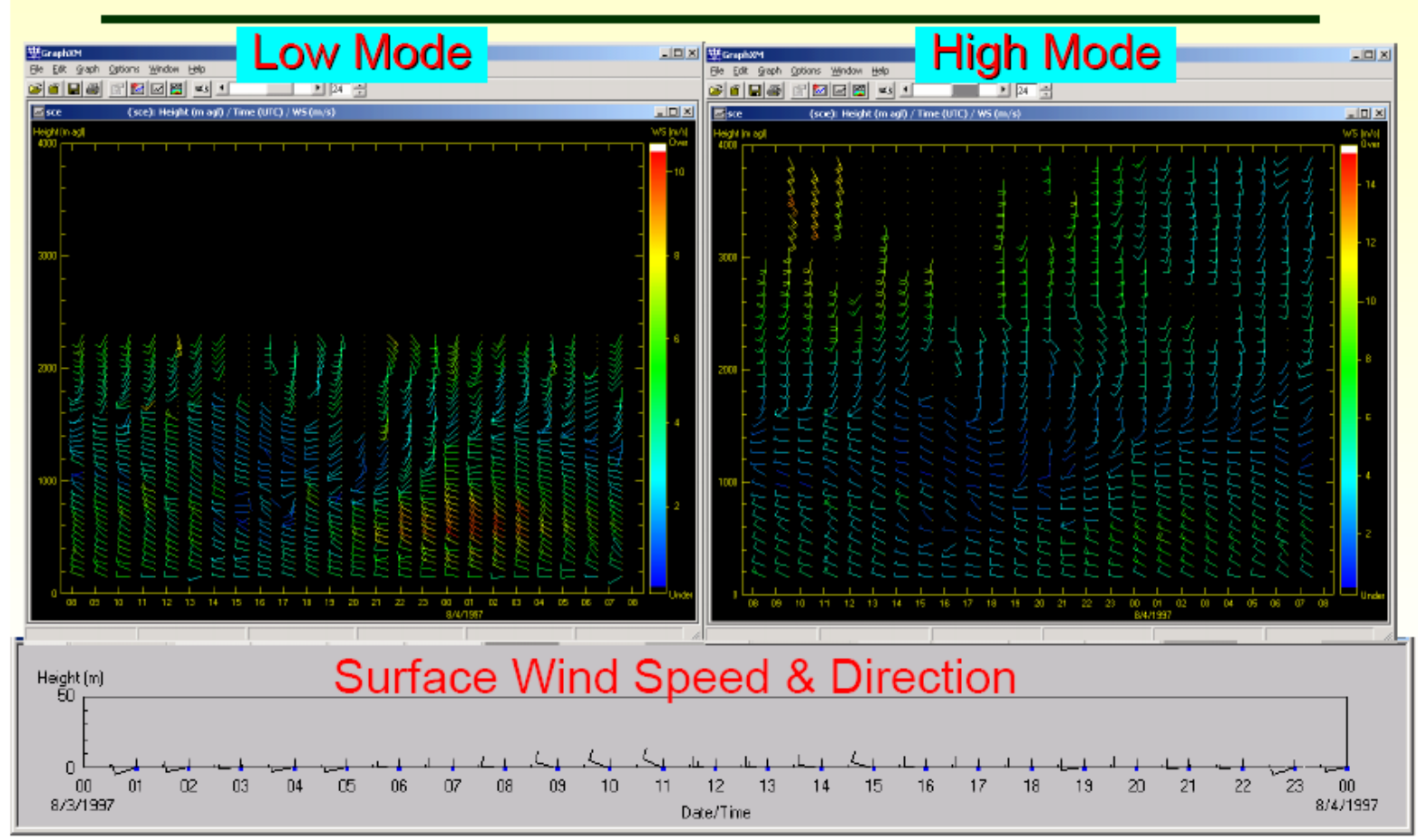

Figure. 5. Graphical presentation of data on the wind over a 24-hour period-08 March 1997 


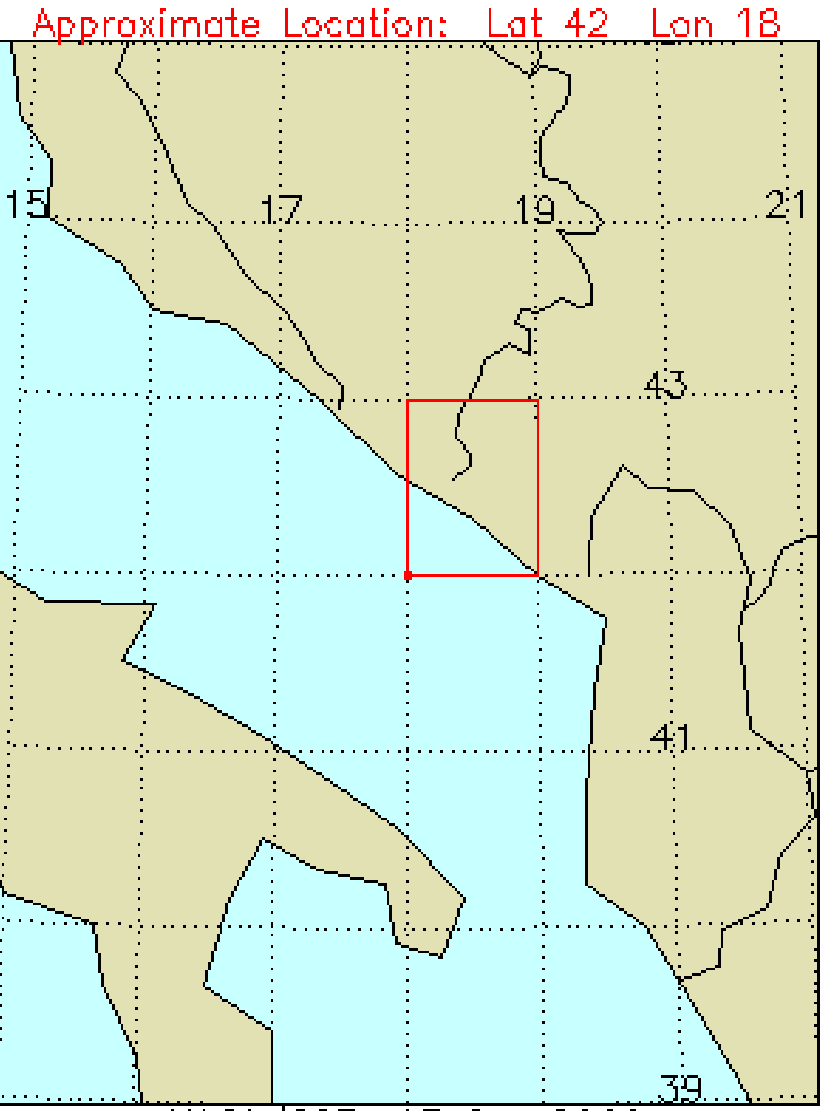

Figure 6. Grid for which there is a wind database on the basis of satellite observations (NASA Surface meteorology and Solar Energy)

Table 2. Monthly Averaged Wind Speed At $60 \mathrm{~m}$ Above The Surface of The Earth for Indicated GMT Times $(\mathrm{m} / \mathrm{s})$

\begin{tabular}{|c|c|c|c|c|c|c|c|c|c|c|c|c|c|}
\hline Lat 42 Lon 17 & Jan & Feb & Mar & Apr & May & Jun & Jul & Aug & Sep & Oct & Nov & Dec & $\begin{array}{c}\text { Annual } \\
\text { Average }\end{array}$ \\
\hline Average@0130 & 6.32 & 6.77 & 6.25 & 5.63 & 4.66 & 4.45 & 5.01 & 5.01 & 4.88 & 5.79 & 6.42 & 6.73 & 5.65 \\
\hline Average@0430 & 6.02 & 6.45 & 5.92 & 5.25 & 4.34 & 4.03 & 4.53 & 4.63 & 4.70 & 5.59 & 6.22 & 6.53 & 5.34 \\
\hline Average®0730 & 5.78 & 6.02 & 5.45 & 4.73 & 3.71 & 3.35 & 3.34 & 3.62 & 3.92 & 5.04 & 5.89 & 6.24 & 4.75 \\
\hline Average® 1030 & 5.35 & 5.65 & 5.52 & 5.22 & 4.08 & 3.86 & 3.20 & 3.52 & 3.58 & 4.71 & 5.46 & 5.78 & 4.65 \\
\hline Average@1330 & 5.43 & 5.84 & 5.76 & 5.62 & 4.58 & 4.51 & 4.01 & 4.21 & 3.90 & 4.82 & 5.43 & 5.78 & 4.98 \\
\hline Average® 1630 & 5.85 & 6.33 & 6.05 & 5.79 & 4.70 & 4.72 & 4.93 & 5.01 & 4.45 & 5.16 & 5.78 & 6.24 & 5.41 \\
\hline Average®1930 & 6.44 & 6.97 & 6.54 & 6.09 & 4.90 & 4.83 & 5.44 & 5.53 & 5.00 & 5.73 & 6.41 & 6.79 & 5.88 \\
\hline Average@2230 & 6.55 & 7.05 & 6.59 & 6.07 & 4.95 & 4.76 & 5.36 & 5.38 & 5.03 & 5.88 & 6.57 & 6.85 & 5.91 \\
\hline
\end{tabular}

Table 3. Monthly Averaged Wind Direction At $50 \mathrm{~m}$ above the surface of the Earth (degrees)

\begin{tabular}{|l|c|c|c|c|c|c|c|c|c|c|c|c|}
\hline Lat 42 Lon 17 & Jan & Feb & Mar & Apr & May & Jun J & Jul & Aug & Sep & Oct & Nov & Dec \\
\hline 10-year Average & 113 & 107 & 106 & 113 & 112 & 101 & 73 & $1^{5} 9$ & 56 & 68 & 79 & 83 \\
\hline
\end{tabular}


Modeling is done according to the logarithm relation (3). The data were derived with the help of images from geo-stationary satellite by the processing of which the vector of wind speed was determined, based on movement of the clouds at the given height.

\section{THE REPUBLIC OF SRPSKA WIND ATLAS}

In this paper the data of U. S. Department of Commerce National Oceanic and Atmospheric Administration NOOA were used [6]. Time averaging was done for the period of 40 years, i.e. longterm time data were obtained on the wind speed. The lines of the same wind speed (isoline) at the annual level for the territory of the Republic of Srpska are shown in Figure 7. This map of wind atlas is relevant for the entire economic life of a wind park, which is equal to 20 to 25 years. It can be seen that the averaged speed at the height of $50 \mathrm{~m}$ is small and insufficient as technologically usable wind potential. This is expected, because the averaged values of wind speed for the great surface and for the mean altitude of the terrain were presented. The relief effect (orography) plays a decisive role in determining the energy potential of the wind at the local level. Also, roughness of the terrain has a big role too.

Average values of the speed during the month of January averaged for a 40-year period (Figure 8) were shown for the sake of comparison. It can be seen that the wind speed in January is considerably higher than the average annual speed.

The wind atlas is usually presented in segments of the given speed intensity range. Such a presentation is shown in Figure 9 for January [7]. In order to get a wind atlas that takes into account terrain orography, wind databases should be compared with the altitude database. Such wind maps are given for different heights above the ground and for more characteristic types of terrain roughness. Usually the heights of $10 \mathrm{~m}, 25 \mathrm{~m}, 50, \mathrm{~m}, 100 \mathrm{~m}$ and $200 \mathrm{~m}$ are used, and four types of roughness of classes: $0,1,2$ and 3 .

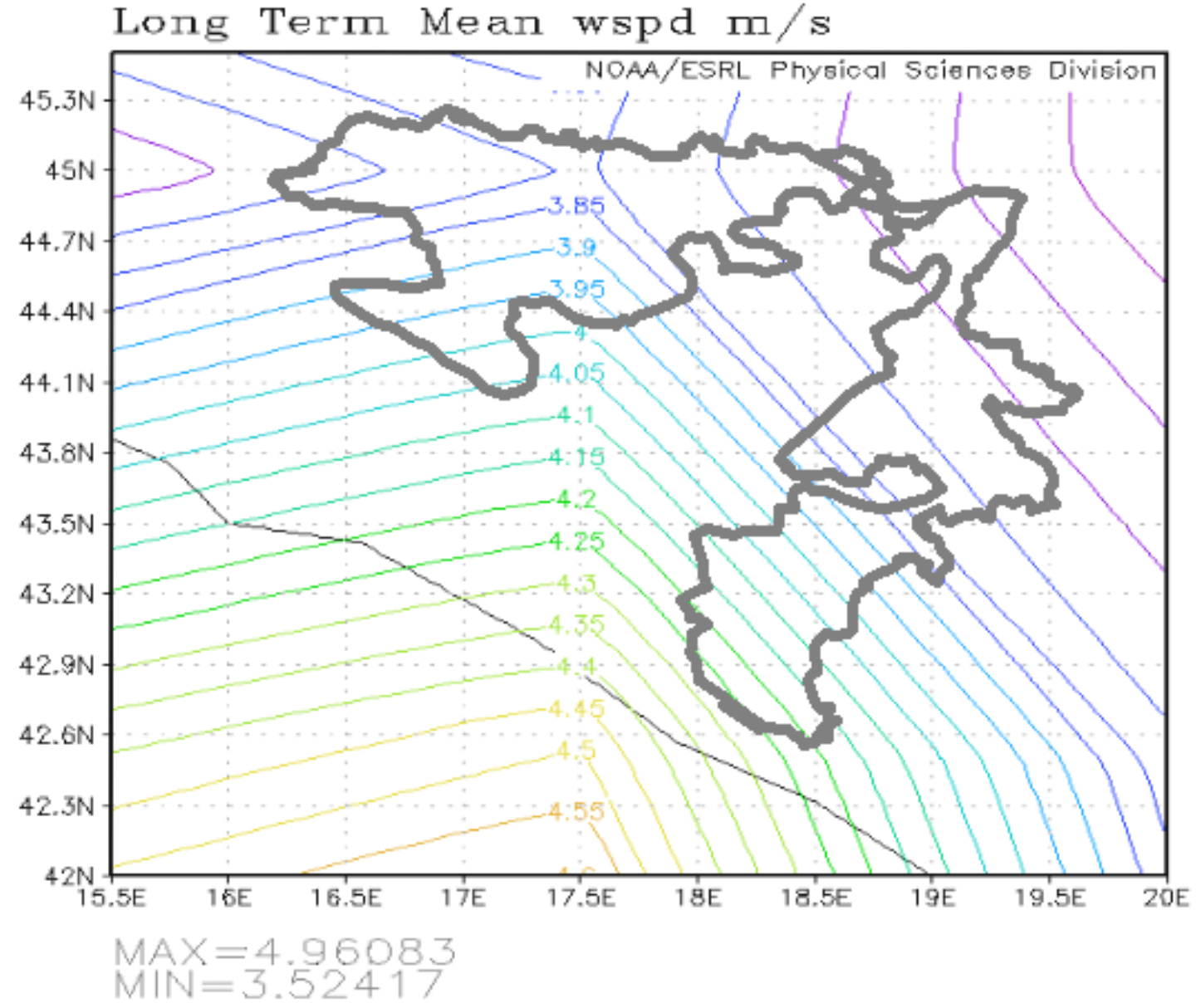

Figure 7. The map of average speed of wind during the year over a 40-year period 

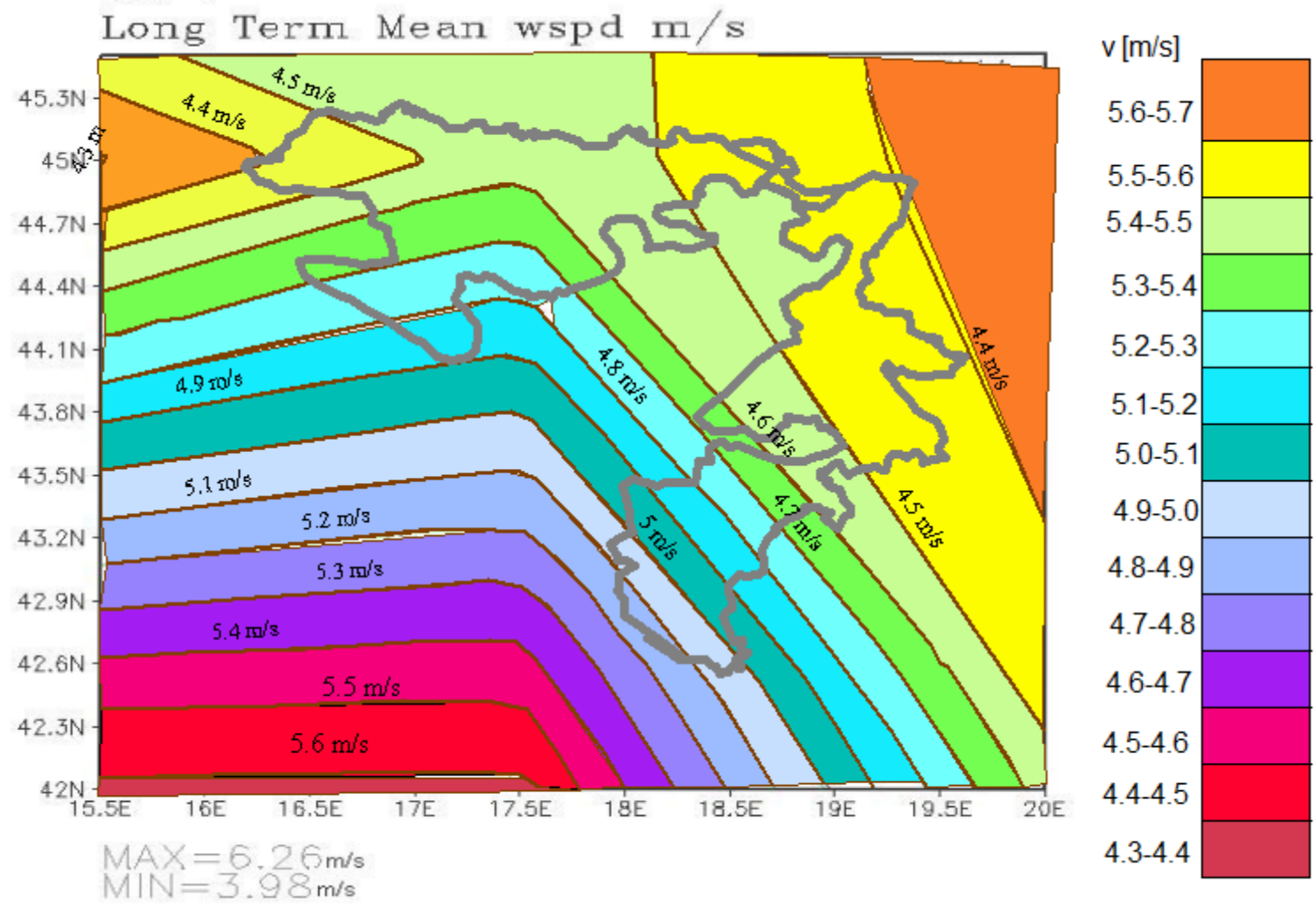

Figure 8. The Republic of Srpska Wind Atlas - January

\section{COMPARISON WITH OTHER RS WIND ATLASES}

Wind atlases that combine the satellite data and orography data are formed on the basis of one of the atmosphere models. Based on the model of the most probable atmosphere condition and the data from European satellites collected during the period 2001-2005, ARMINES Institute designed the Wind Atlas for the Balkans countries presented in Figure 9, on the basis of ECMWF satellite images and the mezzo models. The atlas was given for the height of $50 \mathrm{~m}$ above ground; it does not envisage large, technically usable wind potential in the RS territory.

Based on the analysis NCEP/ NCAR [8] database as a limit condition, by application of nonhydrostatic MM 5 [9] model of simulation on mezzo scale, the company ANEMOS formed a ten-minute database on wind for $\mathrm{BiH}$, for the period 2004-2008. This database was made in horizontal resolution 5 $\mathrm{km} \times 5 \mathrm{~km}$.

Figure 4 presents this map for the height of $100 \mathrm{~m}$ above the ground for the month of January 2007. By comparison with the relief of the area, it can be seen that even at $100 \mathrm{~m}$-height there is a significant impact of orography of terrain on the speed of wind. In order to get a wind map that takes into account the impact of orography, starting from the wind atlas that does not include terrain topography, it is necessary to combine the databases on the wind and on orography.

Isolines of the wind speed from Figure 8 are drawn in Figure 11 on orography terrain map. Such a presentation enables us to assess the speed for each wind speed range, in an area, based on the height of the terrain and the dominant direction of the wind for which the relief represents a shelter, i.e. lee.

It is noteworthy that the wind speed isolines in January were obtained with a presumption of the mean altitude of the ground for the entire area $25 \mathrm{~km}$ $\mathrm{x} 25 \mathrm{~km}$ and with a presumption of homogenous roughness. Correction of the mean speed of wind should be done for the selected location, by including the effect of local relief and local terrain roughness. 


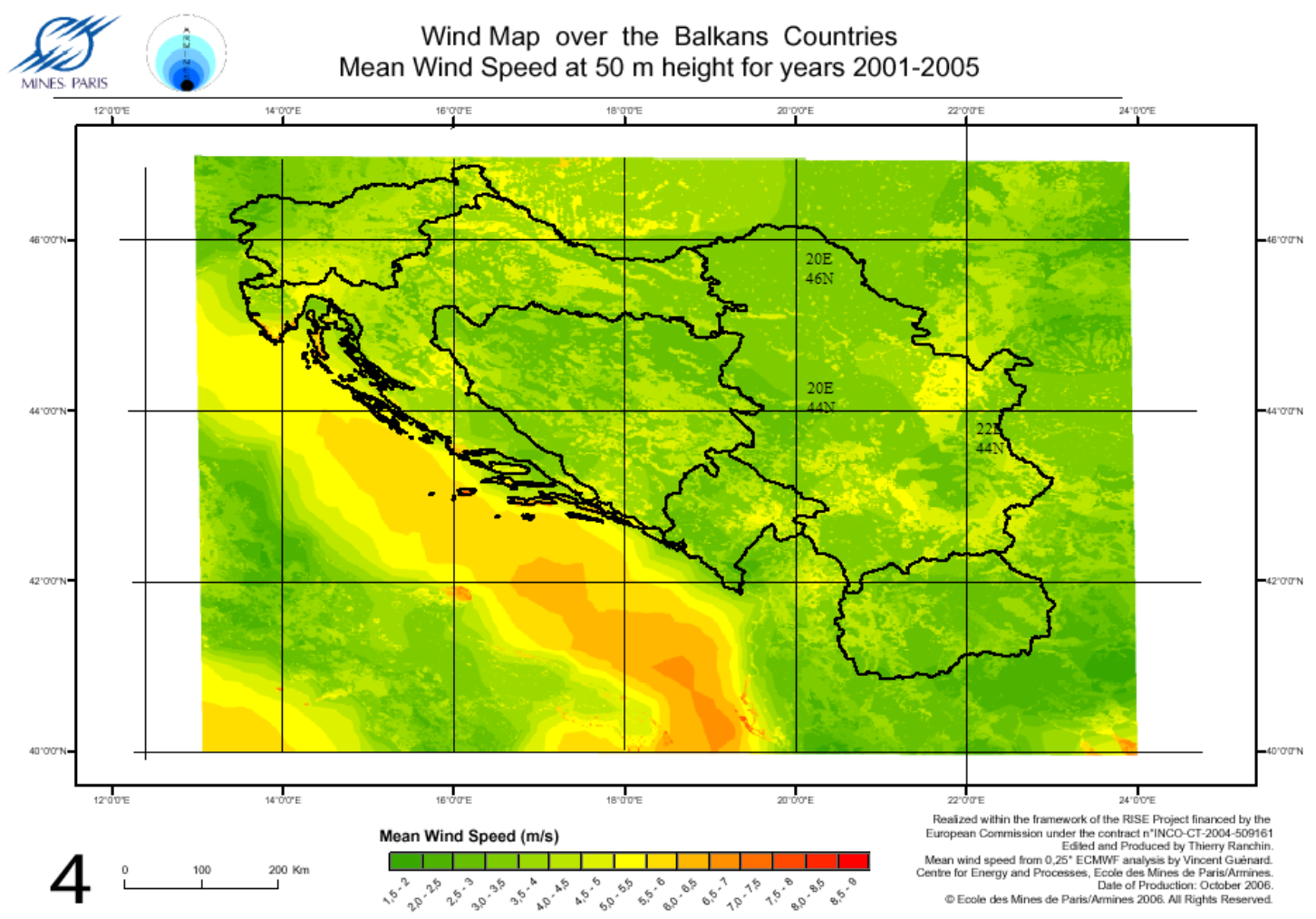

Figure 9. Map of wind at $50 \mathrm{~m}$ above the ground-state of the atmosphere the most likely model (ARMINES)

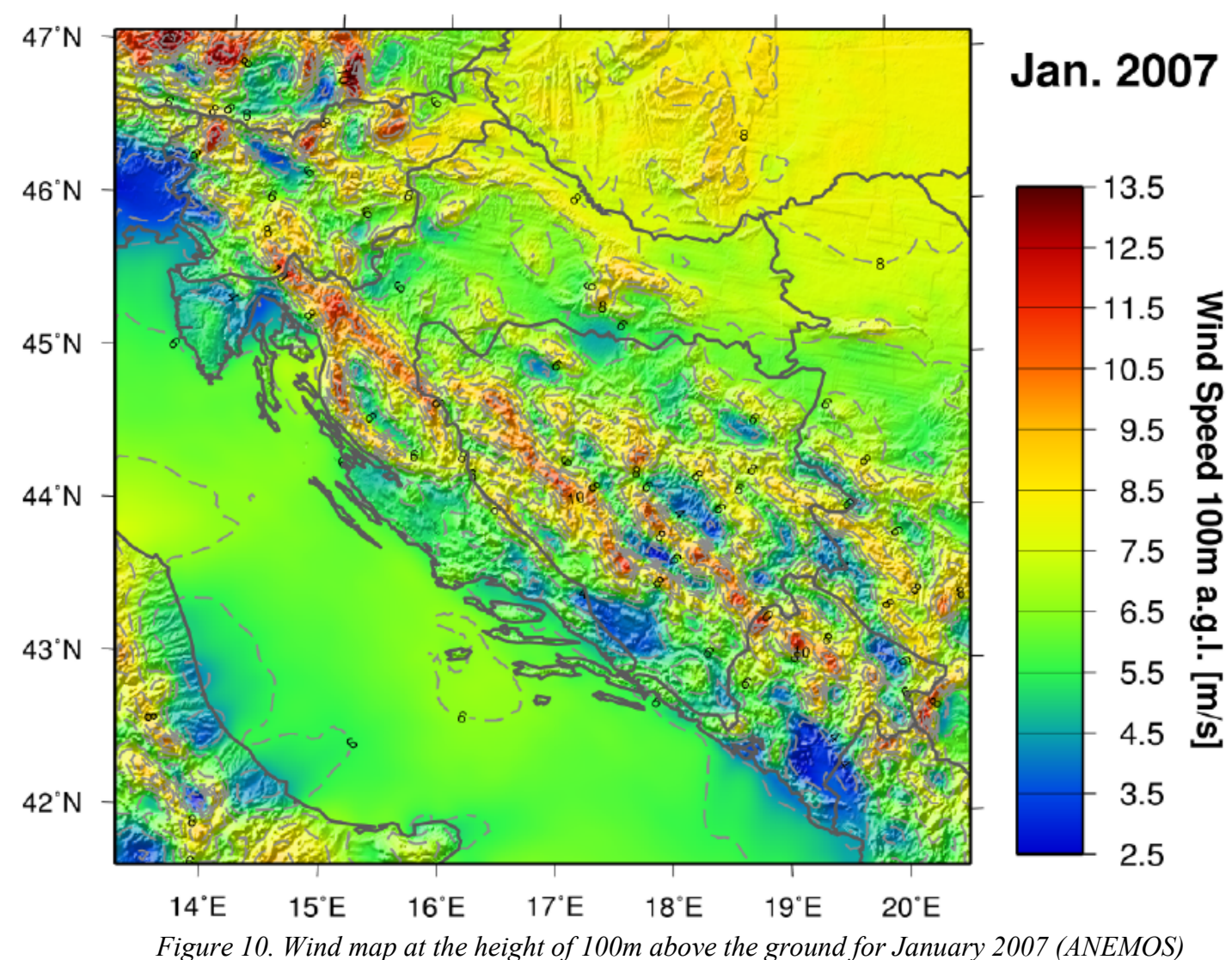


ANEMOS takes into account orography (relief), therefore its wind map very much reminds of the relief in Figure 10. The resolution of ANEMOS map is $5 \mathrm{~km} \times 5 \mathrm{~km}$, while in this paper the map of $25 \mathrm{~km} \times 25 \mathrm{~km}$ resolution was presented. In the area with the wind speed in the given range, a location with the best possible wind based on observation of the relief can be selected by analyzing the map in Figure 10. This is illustrated in the example in Figure 11 which presents the mean wind speed isolines drawn on ANEMOS map from Figure 12. For the selected area in which the wind speed is analyzed, a range of speeds is selected by using isolines, and then the influence of the relief is determined according to the relative ratio of the speeds presented at the scale with colours. The figure serves only as an illustration for the procedure, as the ANEMOS map was given for the height of $100 \mathrm{~m}$ above the ground, while the isolines are presented at the height of $50 \mathrm{~m}$ above the ground.

\section{BUILDING OF WIND POWER PLANTS AND COST-EFFECTIVENESS OF USING THE WIND ENERGY}

When building a wind power plant, as is the case with any other power plant, the factors to be taken into account include energy-economic, technical-technological, spatial-plan and ecological factors.

Energy-economic and technical-technological factors primarily include real, physical possibilities for building of a wind power plant. This means that, in order to select a location for building a wind power plant, one should first check whether there are appropriate speeds and directions of the wind, and then the possibilities for the construction itself should be checked, that is to say, for delivery of the equipment, performance of works, connection to the grid, maintenance, etc.

On the other hand, spatial-plan and ecological factors imply the possibilities for building a wind power plant given the conditions that exist in the area (space): appropriate spatial plan documents that exist in an area and environmental requirements.

There are a few basic facts that should be taken into consideration when planning the area for building of a wind power plant [1]:

- Wind power plants are mainly built on non-built areas (outside the inhabited places), mostly on agricultural, forested or Karst land, or even at sea, whereby an optimum between energy, engineering, spatial-plan and ecological requirements should be found;
- Wind power plants are relatively high structures so they are quite conspicuous;

- If the wind power plant consists of several units, the space between them (the distance is most frequently 200 and $500 \mathrm{~m}$ ) can be used for other purposes, whereby, as a rule, the entire plant or its parts are not being fenced off;

- Upon the expiry of the economic life, the plant is easily removed while leaving no waste behind, and the area remains the same as before;

- Internal electrical grid is installed underground, therefore, it is invisible from the outside.

Unlike other energy plants, the impact of a wind power plant on the environment is relatively small, that is to say, their impact is mostly visual, thanks to the small space that the entire plant occupies on the ground. However, if the wind power plant is composed of a number of units (wind park), the area between them can be used for other purposes (for example for agriculture or livestock farming, etc.), which is not the case with most other power plants that are very frequently also fenced off.

Given the fact that building of wind power plants, in comparison with other power plants, takes relatively short time, the biggest part of the entire process is taken by different preparatory procedures, i.e. mostly for collecting the necessary documentation. The entire process, from an idea to the operation, may be summed up in a number of steps:

- The idea to build and selection of possible locations,

- Collection of necessary data and preliminary research at the site of the future plant (measuring the speed and direction of wind, examining ownership of land, discussion with power utility company, etc. ),

- Elaboration of the conceptual design,

- Procedure for obtaining the decision on location conditions, i.e. the site permit,

- Final study (economic-financial analysis),

- Solving property-legal relations on the land (purchase, lease, rent, concession, etc.),

- Development of the main construction design and procurement of the building permit,

- Building the plant,

- Carrying out operational tests and obtaining the use permit,

- Connection to the grid and putting to operation.

During its economic life, the wind power plant should generate income on the basis of sale of produced electricity, and thus covering the expenses and trying to make profit. Speaking of that, the expenses, i.e. the cost of construction and of putting 
into operation of the wind power plants may be divided into three main groups:

- Investment costs (the biggest part of total expenses),

- Costs of operation and maintenance (make 1.5 to $3 \%$ of total expenses),

- Expenses related to payment of taxes and contributions, capital, etc.

The investment costs are divided into costs depending on the location and construction costs. The costs depending on the location include the costs of real estate (purchase, lease, rent, concession and administrative expenses related thereto), construction of access roads, electrical and telecommunication grid, and additional facilities designed to make the area more livable. Construction costs include all the costs necessary for physical construction of the plant at the selected location.

The average economic life of wind turbines is estimated at about twenty years, i.e. at about 120.000 operating hours, while the economic life of foundations can even be as long as 50 years. This actually means that the same foundations could be used twice, that is to say, for setting of two generations of wind turbines. The time of availability of wind power plants is extremely long and may be as long as $98 \%$, whereby the regular checks and wind power plants repairs should be done every six months as a rule.

Financial evaluation of the project of construction of a wind power plant may be divided to the assessment of liquidity and the assessment of cost-effectiveness. The assessment of liquidity includes forecasting whether the wind plant will be able to meet the expenses through its economic life, while the assessment of cost-effectiveness is based on determination of its economic contribution. The assessment of cost-effectiveness can be done in a few essential ways: by using the method of time return on investment (determining the time necessary to cover the overall investment), by the method of net present value and the method of internal return rate.

\section{Long Term Mean wspd $\mathrm{m} / \mathrm{s}$}
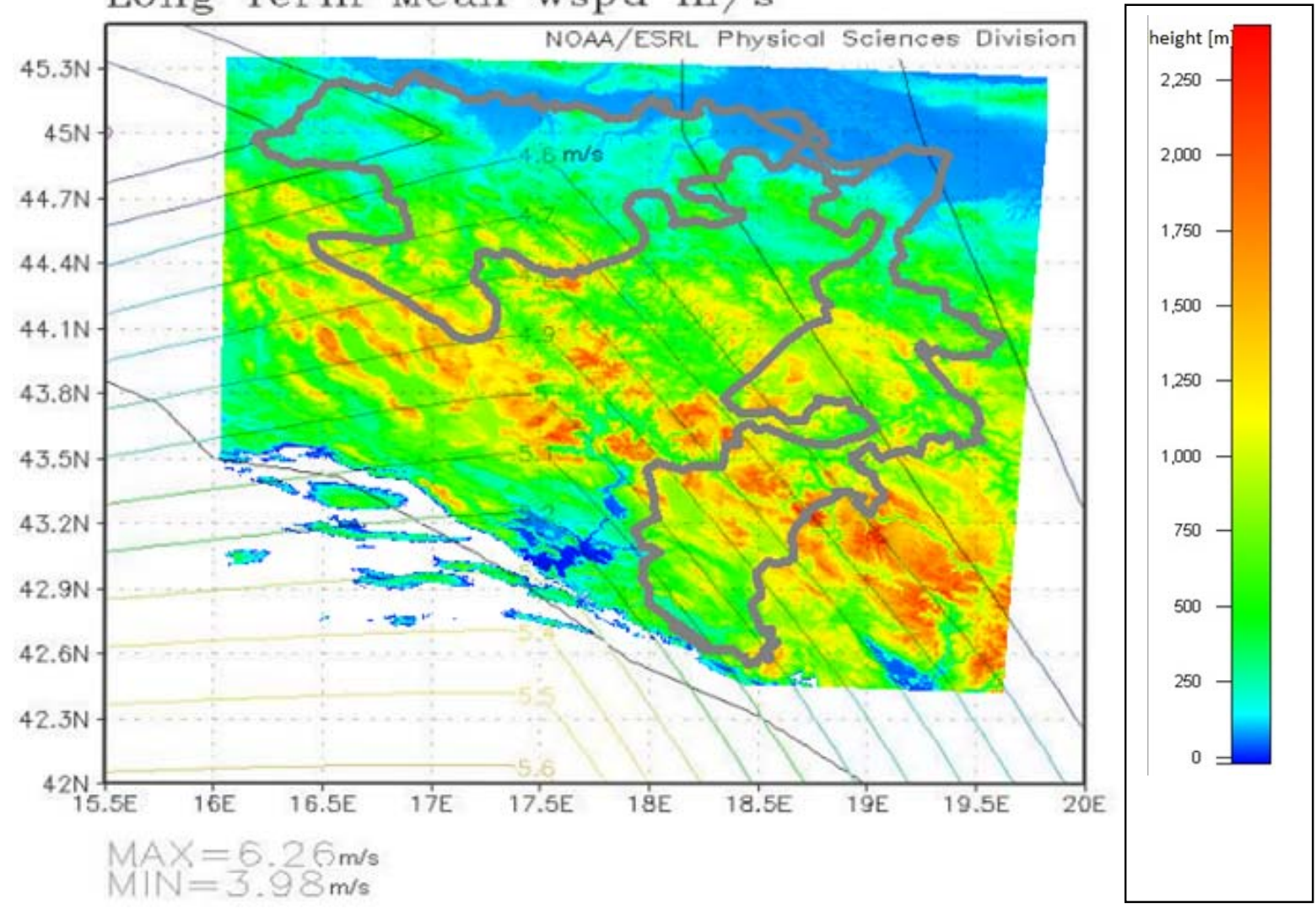

Figure 11. Wind speed isolines on orography map of the ground 


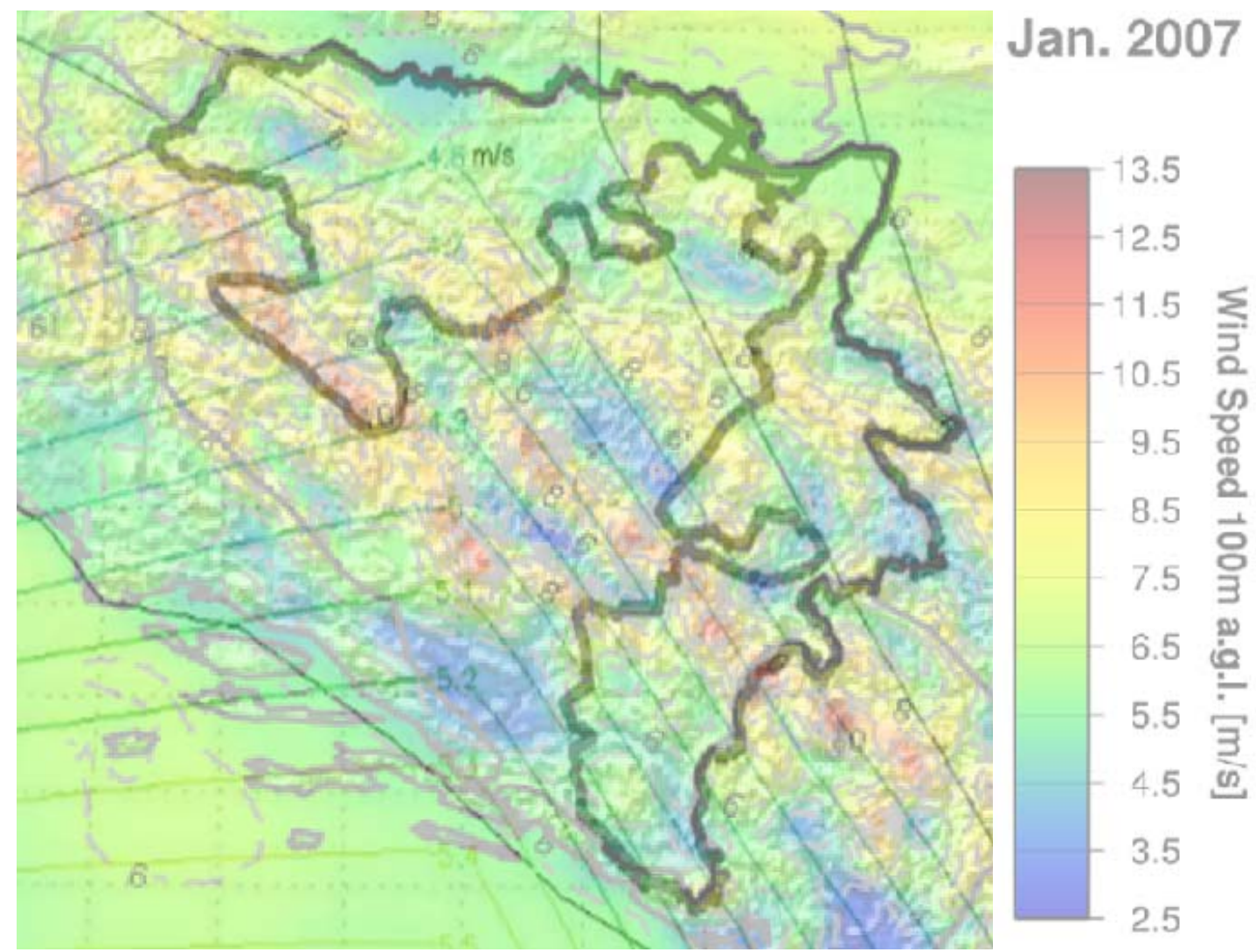

Figure 12. Isoline of average wind speed in January for a period of 40 years (height $50 \mathrm{~m}$ ) marked on the map ANEMOS a

Based on previous experiences in construction of wind generators, an indicative value of the investment from 700 do 1000 EUR per installed $\mathrm{kW}$ was reached. Wind generators, and consequently, the wind farms, have sustained a considerable decrease in price in the last ten years, and that tendency will continue. In this way, the cost of electrical energy produced by wind generators has drastically decreases. This was additionally influenced by a decrease of operating expenses and the growth of efficiency and reliability. Given the fact that with the use of wind energy, as with many other renewable energy sources, there are no fuel costs, the only expenses remaining after the investment construction are the operating and maintenance costs. The investment costs are the costs of construction of the wind generator or wind farm, including the costs of construction for access roads, if necessary, and the costs of connection to the electric power system, which accounts for $75-90 \%$ of the overall expenses [11]. Generally, the locations with appropriate construction conditions for a wind farm are away from the main roads and energy routes, consequently, their connection to them increases the investment costs.
The cost of the wind generator ranges from 600 to $900 €$ per installed $\mathrm{kW}$. With an increase of the wind speed grows the ratio of useful activity, posing a requirement for erecting high poles.

The cost of the energy of the wind is determined on the basis of the following: initial costs for construction of wind generators, interest on invested money and the quantity of produced energy.

The International Energy Agency - IEA published the guidelines in the form of ,Recommended Practices" for the use of wind energy, and they are similar to the guidelines for other forms of renewable energy sources and for thermal plants.

The main assumptions relate to the class of wind generators of capacity from $600-750 \mathrm{~kW}$. According to the experiences from the ,Recommended Practices", the investment costs are increased by $8 \%$ per each new $\mathrm{m} / \mathrm{s}$ of increase of wind speed over $7 \mathrm{~m} / \mathrm{s}$. The quantity of the annual production of electrical energy was reduced by a $10 \%$ loss, although, due to high reliability degree at the level of $98 \%$, real losses may be even lower. 


\section{CONCLUSION}

The first part of the paper analyzes the basic characteristics of the wind and conversion of the wind energy in a wind turbine, with an overview of the capacity factor as one of the elements in evaluation of wind turbine productivity.

Meteorological stations in the Republic of Srpska are relatively well distributed in terms of space, however in order to use the data obtained from them, detailed modeling of each individual station is required, caused by the influence of local relief, the texture of terrain surface (roughness) and obstacles to the wind speed.

The data on the wind were used derived from satellite measurings in $25 \mathrm{~km} \times 25 \mathrm{~km}$ resolution, calculated at the height of $50 \mathrm{~m}$ above the ground and on uniform roughness. By marking the lines of the same wind speed at the terrain relief (orography) map, it is possible to assess the influence of the relief on the speed of the wind in the observed area.

The wind potential in the Republic of Srpska grows going in the direction North-West - Southeast.

Comparison with the wind atlas of the company ANEMOS, in $5 \mathrm{~km} \times 5 \mathrm{~km}$ resolution, shows that, based on the satellite map of the wind and the data on relief, it is possible to choose an area appropriate for setting the specialized measuring station for wind.

At the end of the paper we analyze the spatial conditions, economic factors for construction of wind power plants and cost-effectiveness of using the wind energy.

\section{REFERENCES}

[1] B. Labudović, Renewable energy sources, Energetika, Marketing Zagreb, 2002.

[2] Directive 2009/28/EC of the European Parliament and of the Council, April 23, 2009.

[3] Earth Day, Obama Talks on Wind Power, 2009. http: //www.cbsnews.com/stories/2009/04/22/tech/main 4961315. shtml

[4] I. Troen, E. L. Petersen, The European Wind Atlas, RISø National Laboratory, Roskilde, Denmark, 1989.

[5] M. Zlatanović, D. Mirjanić, V. Zlatanović, I. Popović, Wind energy potential of the Republic of Srpska, SANU, Alternative energy sources and the future of their application 14 (2010) 195-214.

[6] U. S. Department of Commerce National Oceanic and Atmospheric Administration NOOA http:www.doc.gov, http: $\|_{w w w . n o a a . g o v}$

[7] M. Zlatanović, D. Mirjanić and J. Šetrajčić, Energy potentials of wind in the Republic of Srpska, Forum: Renewable Energy Sources, Novi Sad, 2009.

[8] NCEP/NCAR Reanalysis Data provided by the NOAA-CIRES Climate Diagnostics Center, Bouder, Colorado, USA.

[9] MM 5 was developed in cooperation with the Pennsylvania State University and the University Cooperation for Atmospheric Research (UCAR).

[10] M. Đurović, Wind Energy, Sustainable Energy in Asia and the Pacific, International Council for Science (2010) 5-16.

[11] T. Pavlović, Z. Pavlović, Lj. Kostić, S. Jovanović, L. Pantić, R. Stojiljković, Renewable Energy Sources, Adriatic New Neighborhood Programme INTERREG III A, Niš, Serbia, 2008.

gON

\section{УПОТРЕБА ЕНЕРГИЈЕ ВЈЕТРА И ЕНЕРГЕТСКИ ПОТЕНЦИЈАЛ ВЈЕТРА РЕПУБЛИКЕ СРПСКЕ}

\footnotetext{
Сажетак: Климатске промјене изазване емисијом гасова стаклене баште и загађење животне средине условили су, у домену енергетике, нагли пораст коришћења обновљивих извора енергије. Најзначајнији еколошки прихватљив обновљиви извор енергије, који по економским параметрима успјешно конкурише класичним енергетским изворима, јесте енергија вјетра. Земље Европске уније, Америка, Кина, Индија, Аустралија и многе друге, значајним мјерама владе подржавају развој вјетроенергетике.

Коришћењем података са сателита, фирма АНЕМОС је урадила Атлас вјетра РС у резолуцији 5 х 5 км. Подаци земаљских метеоролошких станица са подручја РС могу се ограничено користити због просторног распореда мјерних мјеста и значајног утицаја конфигурације и храпавости околног терена на интерпретацију мјерних резултата. У циљу одређивања локалног енергетског потенцијала вјетра инсталирано је неколико специјализованих мјерних станица за вјетар на подручју Романије и у
} 
D. Lj. Mirjanić, M. Zlatanović, Wind energy use and wind energy potential of the Republic of Srpska

околини Требиња. У овом раду приказани су први резултати одређивања глобалне расподјеле брзине вјетра на подручју РС према методологији Европског атласа коришћењем сателитских мјерења са резолуцијом 25 х 25 км. Показано је да брзина вјетра на територији РС расте у правцу сјеверозапад-југоисток, што је у сагласности са доступним резултатима других истраживања. Добијене мапе вјетра могу се користити за одређивање локација које су повољне за постављање специјализованих мјерних станица за вјетар.

На крају рада су анализирани економски аспекти коришћења енергије вјетра. Српске.

Кључне ријечи: енергија вјетра, вјетрогенератори, Атлас вјетра Републике 